\title{
Developing Songs for Elementary School Students with the Support of Music Notation Software
}

\author{
J. Julia ${ }^{1, *}$, Prana Dwija Iswara ${ }^{1}$, Sandie Gunara ${ }^{2}$, Tedi Supriyadi ${ }^{3}$ \\ ${ }^{1}$ Prodi PGSD Sumedang, Universitas Pendidikan Indonesia, Bandung, Indonesia \\ ${ }^{2}$ Department of Pendidikan Seni Musik, Universitas Pendidikan Indonesia, Bandung, Indonesia \\ ${ }^{3}$ Prodi PGSD Pendidikan Jasmani Sumedang, Universitas Pendidikan Indonesia, Bandung, Indonesia
}

Copyright $\bigcirc 2019$ by authors, all rights reserved. Authors agree that this article remains permanently open access under the terms of the Creative Commons Attribution License 4.0 International License

\begin{abstract}
Elementary school students need to be exposed to song's melodies that match their vocal range. When the teacher makes new songs, the melody needs to be adjusted to their students' abilities. This study aims at producing songs for elementary school students by employing Four-D Model (Defining, Designing, Developing, and Disseminating). This study was conducted through testing to 94 elementary students in West Java province chosen by purposive sampling. The research findings showed that: (1) students encountered some difficulties in singing a song in ${ }^{\#} \mathrm{G}^{3}$ to $\mathrm{D}^{5}$ note range, and all students were more capable of singing in ${ }^{\#} \mathrm{~A}^{3}$ to $\mathrm{C}^{5}$ note range; and (2) students encountered some difficulties in singing the song's melody in the 700 cent interval, both in decreasing and increasing melodic contours, and they also encountered some difficulties in singing the song's melody from eighth note $(1 / 4)$ to quarter note $(1 / 8)$. The implication of this study is that there is an urgency to compose a simple song for elementary students aiming at the success of music learning, or on the contrary; the children's musical competence should be developed in their early age to reach a more complex note range and interval.
\end{abstract}

Keywords Developing Songs, Elementary School, Music Notation Software, Vocal Range

\section{Introduction}

Range of song's melodies in elementary school students is different from adults. Therefore, the music learning of elementary school students requires songs that suit their needs and abilities, both from the aspects of the lyrics and the melody of the song. Many songs were created for children, however, the match between tone intervals and children's abilities have not yet known for certain. In Indonesia, currently, new contextual songs are needed to meet the needs of music learning in elementary schools, based on the latest course theme proposed in the curriculum.

When creative teachers intend to create new songs, they generally do not know the boundaries of children's voices, so there is an urgency to provide some guidelines for making songs, especially with regard to tone boundaries that can be sung by elementary students. Meanwhile, teachers generally only use songs that are available in the market, without critically analyzing its suitability with the students' singing ability beforehand. Therefore, studies on the range of vocal intervals in elementary school students need to be carried out to address this issue.

Various studies have been conducted on the issues of vocal range, such as Welch (1979), Jersild and Bienstock (1934), Wassum (1979), Flowers and Dunne-Sousa (1990), and others. In one of the mentioned studies, Wassum (1979) has given us a foothold to use songs that are written in keys that will not exceed the lowest nor highest ranges for most children. J Julia, Hakim, and Fadlilah (2019) examined how to develop method on song teaching for elementary school teachers, and how to make song using technology (J. Julia, Iswara, \& Supriyadi, 2018). Another study on song-making was done by Barrett (2010). His study involved a three-year longitudinal project that has examined the role of invented song-making and music engagement in 18 young children's (aged approximately 18-48 months) skill on identity work and self-making. Findings signify that invented song and music-making built on young children's have enhanced their 'communicative musicality' experiences and provided narrative structures when they perform and proclaim multiple ways in musical storying and story-telling. A recent study on song-making was carried out by Ward, Price, Davis, and Crowther (2018). They explored the extent to which music-oriented high school students obtain benefits when participating in 'Songwriting To Learn', which is a possible variation on the Writing To Learn (WTL) model of instruction. This study discovered that 
science-related songs led the students to use their practice-linked identities in the music domain to express their growing understanding of science. Unlike the aforementioned previous studies, this study emphasizes on analyzing vocal range limitations of elementary school students in Indonesia, hence, creative teachers are expected to not mistakenly making and teaching new songs to elementary school children.

\section{Methods}

This study employed Thiagarajan's Four-D model, which consists of: Defining, Designing, Developing, and Disseminating (Thiagarajan, 1974). In the Defining stage, an analysis of the problems and the various needs needed to make a melody of songs that match the characteristics of students were conducted. In the Designing stage, draft songs were tested. In the Developing stage, limited tests, field tests, and validation tests on all song drafts were conducted. In the Disseminating stage, songs were disseminated through training to elementary school teachers, and demonstrated through music festivals. The research subjects were 94 elementary school students from West Java province, Indonesia, which consisted of $4^{\text {th }}-6^{\text {th }}$ grader, who were selected using purposing sampling techniques. Those selected students were assessed to have a good rate during singing.

\section{Results}

\subsection{Defining}

In this stage, an investigation of the problems, and the numerous requirements needed to make a melody of songs that are appropriate for the requirements of students were investigated. The results of the analysis obtained the following important points:

\subsubsection{Music Curriculum Analysis}

The most-recent curriculum in Indonesia includes music and vocal learning from elementary school to high school. Especially for vocal curriculum (music education) in elementary schools, teachers are required to teach songs with lyrics, solmization, and body movements.

\subsubsection{Analysis of Music Teaching}

The survey results of elementary school teachers indicated that the majority of teachers have not had sufficient competence to teach music, especially to teach vocals to students. Special strategies are needed so that the teacher can teach the song correctly.

\subsubsection{Analysis of Music Material}

Vocal teaching usually takes free song material available in various media. Regrettably, the teachers did not create melodic songs, and the lyrics are not according to the needs of the students. In fact, the curriculum in Indonesia has instructed contextual and national character learning. Therefore, more suitable songs are essential to be made to address the needs of the school environment.

\subsubsection{Analysis of Student Characteristics}

Children in elementary school age already have the skills to sing song's melodies, follow the rhythm, follow the tempo of the song, and give expression to the song. However, song's melodies that can be sung by elementary school students are in a range of melodies that are different from the range of melodic songs for adults. Therefore, songs created for elementary school students need to be adapted to their abilities in achieving the highest and lowest sounds.

\subsection{Designing}

In this stage, nine draft songs were composed. All ranges of new songs' melodies created refer to previous study (Putra, 2015) that illustrates children's vocal range is from $\mathrm{A}^{3}$ to $\mathrm{F}^{5}$, as depicted in Figure 1 below.

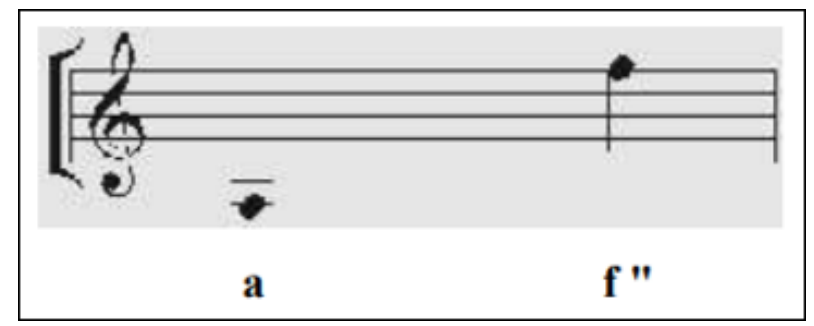

Figure 1. Tone range for children

\subsubsection{The Process of Drafting Songs}

The songs were composed using music notation software, Sibelius. Refining the collaboration between the knowledge bases of software growth and music education could improve innovative educational afford (Cheng \& Leong, 2017). The steps taken to make a song in the Sibelius application are: (1) preparing a new paper; (2) setting up documents and time signatures; (3) choosing musical instruments; and (4) writing song's melodies. Phase 1-3 is depicted in the Figure 2 below. 


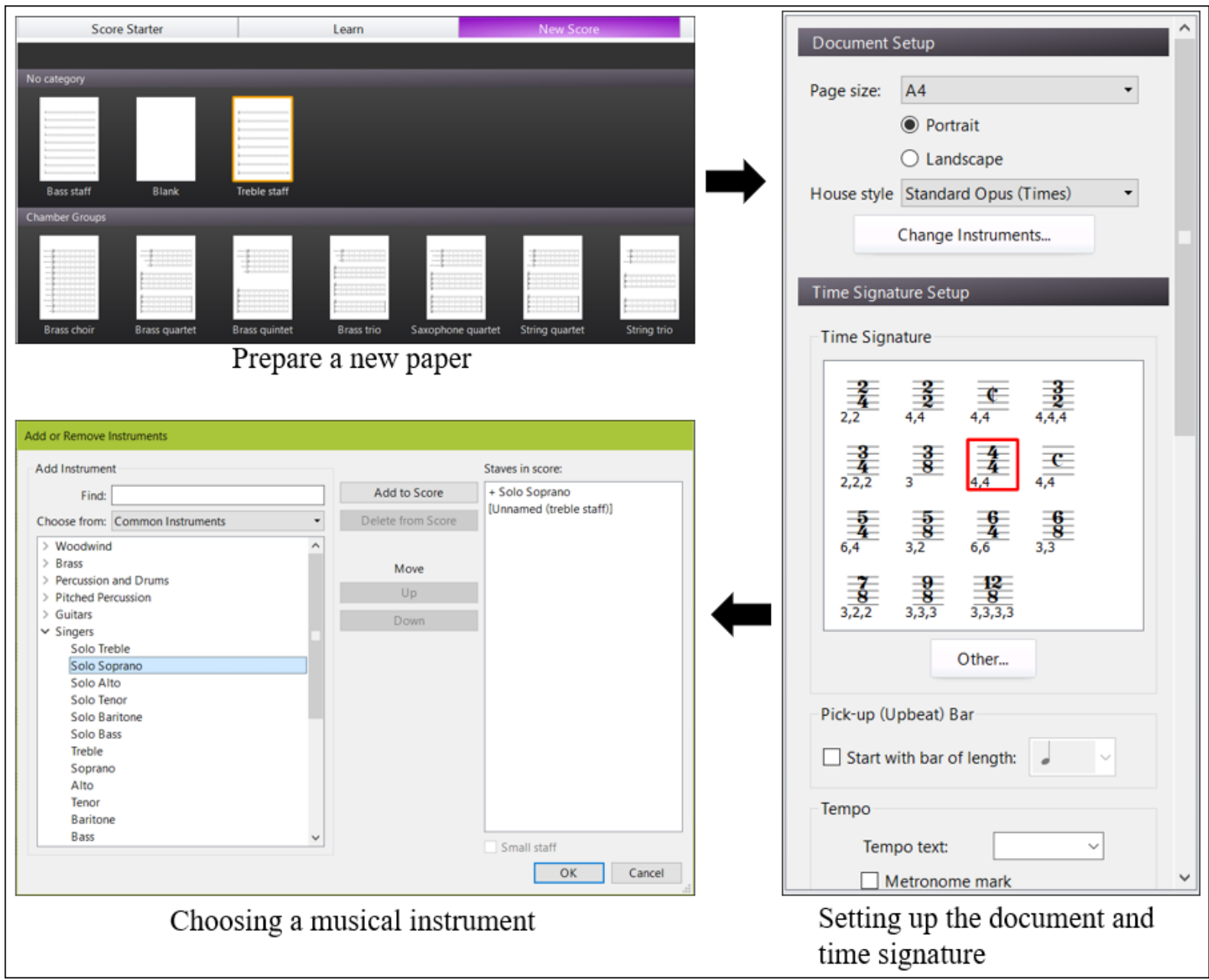

Figure 2. The stages of making a song's melody

Writing song's melodies were done on blank sheet music using the keypad that has been provided according to the needs in writing music notation in general. The keypad is selected by clicking, and also writing it on sheet music simply by clicking one by one according to the song's melody the composer wants (see Figure 3). The creativity required in this stage is the ability to make melodies of songs that are relatively original and have good song forms.

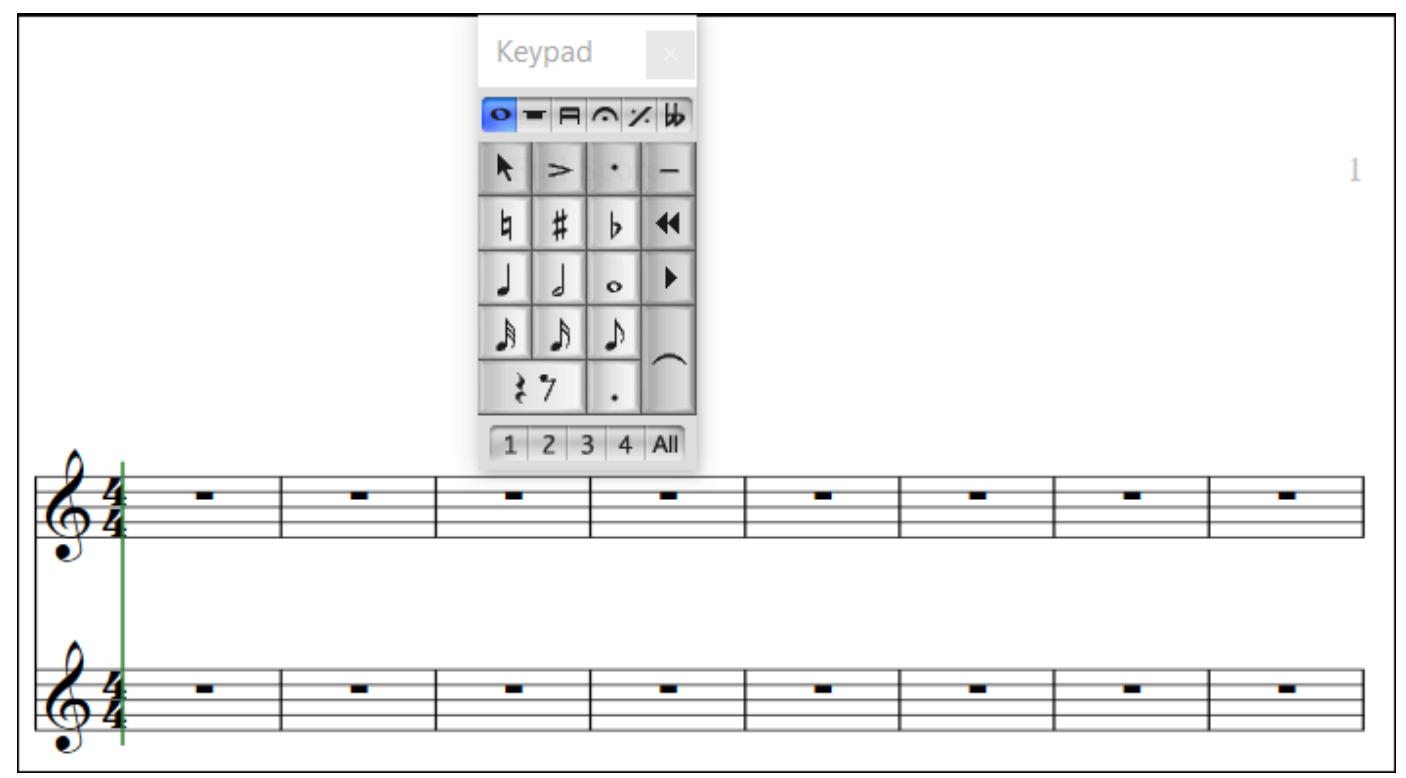

Figure 3. Sheet music that is ready for use 


\subsubsection{The Results of the Drafting of the Song}

There were nine songs made to be taught to students. Details on the scale and range interval of the draft song are presented in Table 1 below.

Table 1. Nine draft songs

\begin{tabular}{|c|c|c|}
\hline Song Titles & Scale & $\begin{array}{l}\text { Interval } \\
\text { Range }\end{array}$ \\
\hline $\begin{array}{c}\text { Merenung Pencipta (Contemplating the } \\
\text { Creator) }\end{array}$ & $\mathrm{Do}=\mathrm{C}$ & ${ }^{\#} \mathrm{G}^{3}-\mathrm{D}^{5}$ \\
\hline Berkata Jujur (Telling the Truth) & $\mathrm{Do}=\mathrm{C}$ & $C^{4}-C^{5}$ \\
\hline Bangun Toleransi (Build Tolerance) & $\mathrm{Do}=\mathrm{C}$ & $\mathrm{B}^{3}-\mathrm{C}^{5}$ \\
\hline Mari Disiplin (Let's Discipline) & $\mathrm{Do}=\mathrm{C}$ & $B^{3}-A^{4}$ \\
\hline $\begin{array}{c}\text { Terus Bekerja Keras (Keep Working } \\
\text { Hard) }\end{array}$ & $\mathrm{Do}=\mathrm{C}$ & $\mathrm{C}^{4}-\mathrm{C}^{5}$ \\
\hline Mari Berkarya (Let's Create) & $\mathrm{Do}=\mathrm{G}$ & $C^{4}-A^{4}$ \\
\hline $\begin{array}{l}\text { Belajar Hidup Mandiri (Learning to be } \\
\text { Independent) }\end{array}$ & $\mathrm{Do}=\mathrm{C}$ & $C^{4}-A^{4}$ \\
\hline $\begin{array}{c}\text { Beda Itu Biasa (Differences are } \\
\text { Common) }\end{array}$ & $\mathrm{Do}=\mathrm{C}$ & $C^{4}-C^{5}$ \\
\hline Ingin 'Ku Belajar (I Want to Learn) & $\mathrm{Do}=\mathrm{C}$ & $\mathrm{B}^{3}-\mathrm{C}^{5}$ \\
\hline
\end{tabular}

\subsection{Developing}

In this stage, various developments on the creation of nine drafts song processes were carried out. The process started from limited tests, field tests, validation tests, expert team validation, to the revision process.

\subsubsection{Limited Test}

Limited test in one elementary school with 18 students was conducted. The aim is to analyze the feasibility of the melody of the song so that it could be sung by students. All students sang nine songs after memorizing each song one by one. After all students could sing all songs, they then filled out the survey. The survey results and observations were used as guidance to revise songs that were considered difficult to sing.

\subsubsection{Revised of Limited Draft Test}

Based on the results of survey and observations, revisions were done to a song by changing the intervals and scales of songs. There were many students who could not reach certain notes of songs entitled 'Merenung Pencipta'. The research findings showed that students encountered some difficulties in singing a song in \#G3 to D5 note range. All students were more capable of singing in \#A3 to C5 note range.

\subsubsection{Field Test}

Field tests were done in three elementary schools with a total of 56 students. The songs provided are the result of a limited test. As done previously in limited tests, in this stage, all students were also taught nine songs and filled out surveys after all the songs could be sung by them. The results of the field tests were used to improve all of the songs.

\subsubsection{Revised of Field Draft Test}

The results of the field tests indicated the need to revise a song entitled 'Terus Bekerja Keras' because it the song's melody was considered too high, hence, difficult to reach by the students. The revised song comes from $\mathrm{Do}=\mathrm{C}$ in the $\mathrm{C}^{4}-\mathrm{C}^{5}$ tonal range, changed to Do $=$ Bes in the $\mathrm{Bes}^{4}-\mathrm{Bes}^{5}$ tone range. Students also encountered some difficulties in singing the song's melody in the 700 cent interval, both in decreasing and increasing melodic contours, and they also encountered some difficulties in singing the song's melody from eighth note $(1 / 4)$ to quarter note $(1 / 8)$. The most difficult song to reach is the first song, because there was a tone that was too low and too high. Changing the scale was done by raising and lowering the song's melody..

\subsubsection{Validation Test}

In this stage, validation tests were carried out in one school district different with schools where there were limited tests and field tests. The number of students who took the validation test was 20 students. The purpose of the validation test is to ensure that the songs that have been tested are limited and the field tests really match the abilities of elementary school students.

The majority of students could sing all the songs well. However, none of the songs that were successfully sung were perfect. This is due to the ability of students who could not follow the melody of the song exactly as the melody of the song written on the score, even though the song's melody or interval song is very simple. It is possible that children's singing range is more limited than the vocal range in their natural sound making (Flowers \& Dunne-Sousa, 1990; Kim, 2000; Moore, 1991). Basically, a child's vocal abilities will develop if $\mathrm{s}$ /he follows a series of vocal exercises, such as training in breathing techniques, frasering, resonance, articulation, and intonation (Putra, 2015).

\subsubsection{Expert Team Validation}

In this study, three music and vocal experts were involved. They were asked to evaluate nine songs and to review the quality of the melodic contours, the type of rhythm, the tempo of the songs, and the shape of the songs. The results of the expert team's assessment of aspects of the melody contour are presented in the Table 2 below. 
Table 2. Expert team validation on the contour aspects of song's melodies

\begin{tabular}{|c|c|c|c|c|}
\hline \multirow{2}{*}{ Song title } & \multicolumn{2}{|c|}{ Melody contour scores (10-100) } & \multirow{2}{*}{ Average score } \\
\cline { 2 - 4 } & Expert 1 & Expert 2 & Expert 3 & 90.00 \\
\hline Merenung Pencipta & 90 & 95 & 85 & 91.67 \\
\hline Berkata Jujur & 90 & 95 & 90 & 86.67 \\
\hline Bangun Toleransi & 90 & 85 & 85 & 88.33 \\
\hline Mari Disiplin & 85 & 90 & 90 & 86.67 \\
\hline Terus Bekerja Keras & 85 & 90 & 85 & 86.67 \\
\hline Mari Berkarya & 85 & 90 & 85 & 86.67 \\
\hline Belajar Hidup Mandiri & 85 & 90 & 85 & 91.67 \\
\hline Beda Itu Biasa & 90 & 95 & 90 & 91.67 \\
\hline Ingin 'Ku Belajar & 90 & 95 & 90 & \\
\hline
\end{tabular}

Table 2 above shows that the contour aspects of the melody of all the songs have been assessed well by the expert team. This is indicated by the average score that is in the range 86.67 to 91.67 . The expert team recommended that the songs need to be tested in a wider area to see the interests of the community, for example, broadcasting through YouTube.

\subsubsection{Song Refinements}

The draft songs were developed according to cases obtained, through limited testing until validation tests. The development of the nine song products can be seen in Table 3 below.

Table 3. Development of draft songs

\begin{tabular}{|c|c|c|c|c|c|c|}
\hline \multirow{2}{*}{ Song Title } & \multicolumn{2}{|c|}{ Draft song } & \multicolumn{2}{|c|}{ Revised of limited draft test } & \multicolumn{2}{|c|}{ Revised of field draft test } \\
\hline & Scale & Interval Range & Scale & Interval Range & Scale & Interval Range \\
\hline Merenung Pencipta & $\mathrm{Do}=\mathrm{C}$ & ${ }^{\#} \mathrm{G}^{3}-\mathrm{D}^{5}$ & $\mathrm{Do}=\mathrm{D}$ & ${ }^{\#} A^{3}-C^{5}$ & $\mathrm{Do}=\mathrm{D}$ & ${ }^{\#} A^{3}-C^{5}$ \\
\hline Berkata Jujur & $\mathrm{Do}=\mathrm{C}$ & $\mathrm{C}^{4}-\mathrm{C}^{5}$ & Do $=\mathrm{C}$ & $\mathrm{C}^{4}-\mathrm{C}^{5}$ & $\mathrm{Do}=\mathrm{C}$ & $C^{4}-C^{5}$ \\
\hline Bangun Toleransi & $\mathrm{Do}=\mathrm{C}$ & $\mathrm{B}^{3}-\mathrm{C}^{5}$ & Do $=C$ & $\mathrm{~B}^{3}-\mathrm{C}^{5}$ & Do $=C$ & $\mathrm{~B}^{3}-\mathrm{C}^{5}$ \\
\hline Mari Disiplin & $\mathrm{Do}=\mathrm{C}$ & $B^{3}-A^{4}$ & Do $=C$ & $B^{3}-A^{4}$ & $\mathrm{Do}=\mathrm{C}$ & $B^{3}-A^{4}$ \\
\hline Terus Bekerja Keras & $\mathrm{Do}=\mathrm{C}$ & $\mathrm{C}^{4}-\mathrm{C}^{5}$ & $\mathrm{Do}=\mathrm{C}$ & $\mathrm{C}^{4}-\mathrm{C}^{5}$ & Do $=$ Bes & $\mathrm{Bes}^{4}-\mathrm{Bes}^{5}$ \\
\hline Mari Berkarya & Do $=\mathrm{G}$ & $\mathrm{C}^{4}-\mathrm{A}^{4}$ & $\mathrm{Do}=\mathrm{G}$ & $C^{4}-A^{4}$ & $\mathrm{Do}=\mathrm{G}$ & $C^{4}-A^{4}$ \\
\hline Belajar Hidup Mandiri & Do $=C$ & $C^{4}-A^{4}$ & $\mathrm{Do}=\mathrm{C}$ & $C^{4}-A^{4}$ & $\mathrm{Do}=\mathrm{C}$ & $\mathrm{C}^{4}-\mathrm{A}^{4}$ \\
\hline Beda Itu Biasa & $\mathrm{Do}=\mathrm{C}$ & $C^{4}-C^{5}$ & Do $=C$ & $C^{4}-C^{5}$ & Do $=C$ & $C^{4}-C^{5}$ \\
\hline Ingin 'Ku Belajar & Do $=C$ & $B^{3}-C^{5}$ & $\mathrm{Do}=\mathrm{C}$ & $\mathrm{B}^{3}-\mathrm{C}^{5}$ & $\mathrm{Do}=\mathrm{C}$ & $\mathrm{B}^{3}-\mathrm{C}^{5}$ \\
\hline
\end{tabular}

It can be inferred from Table 3that there were two scale changes in two songs entitled Merenung Pencipta and Terus Bekerja Keras. There are no song's melodies that are lower than tone ${ }^{\#} \mathrm{~A}^{3}$ and there are no song's melodies higher than the $\mathrm{C}^{5}$. For the process of changing the song scale on a notation, from $\mathrm{Do}=\mathrm{C}$ to $\mathrm{Do}=\mathrm{D}$ on the song Merenung Pencipta, for example, a scale change facility is used in the menu Key Signature (see Figure 4), through this menu, the song scale changes according to the chosen scale.

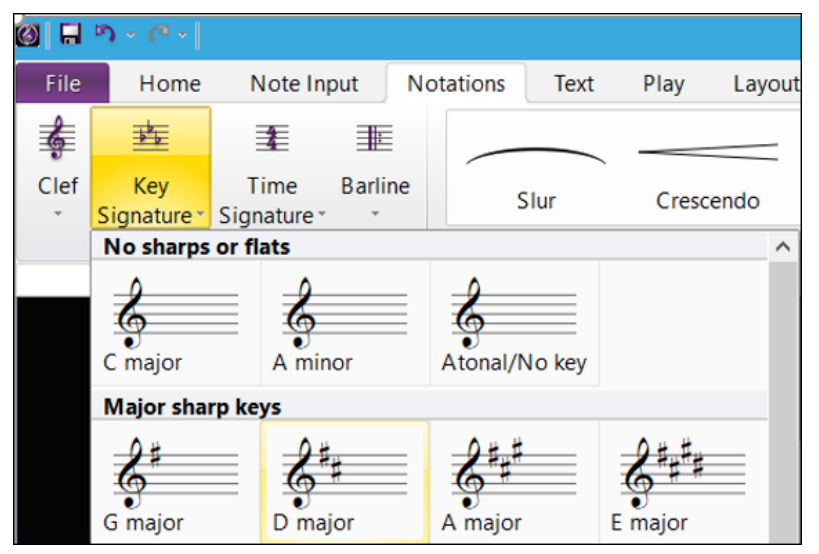

Figure 4. Change the scale of $\mathrm{C}$ major to D major 
When the scale is changed, the note position of the song must be shifted all to one level higher, from the C major position to the $\mathrm{D}$ major position. This can be done by a technique of blocking all notes and sliding them using arrows on the computer keyboard because when all the notes are blocked, all notes will shift according to the direction of the arrow. The last step is to correct the notes that are not in place, such as note G (see Figure 5), which still have the 'Flat' sign (the note sounds lower) and must be returned to the $\mathrm{G}$ tone by sliding and returning to the original place, or clicking note and press the 'Flat' icon on the keypad.

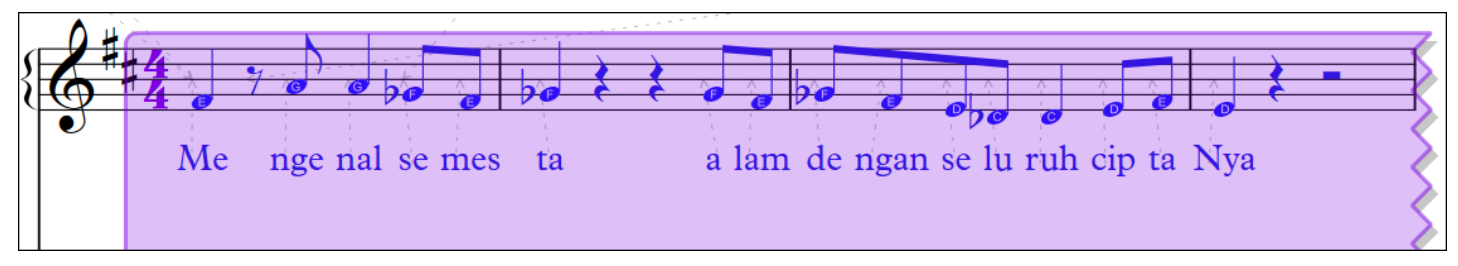

Figure 5. Blocking and shifting notes

\subsection{Disseminating}

After nine songs passed the validation test and assessed by the expert team, the last stage of the development of these songs was to disseminate it to elementary school teachers and prospective students of preservice elementary school teachers. The developed songs were recorded, reproduced into audio CDs, and disseminated to be used at schools. Dissemination was carried out through training for elementary school teachers. Teachers were taught all songs, and they were assigned to teach back to students in their respective institutions. The results of their teaching were then presented through the festival, because the festival has the potential to produce a strong community (J. Han, Wang, Zheng, \& Zhang, 2017; Laing \& Mair, 2015; Little, Burger, $\&$ Croucher, 2018). Figure 6 shows a student singing a song from the development of a national character-themed music festival.

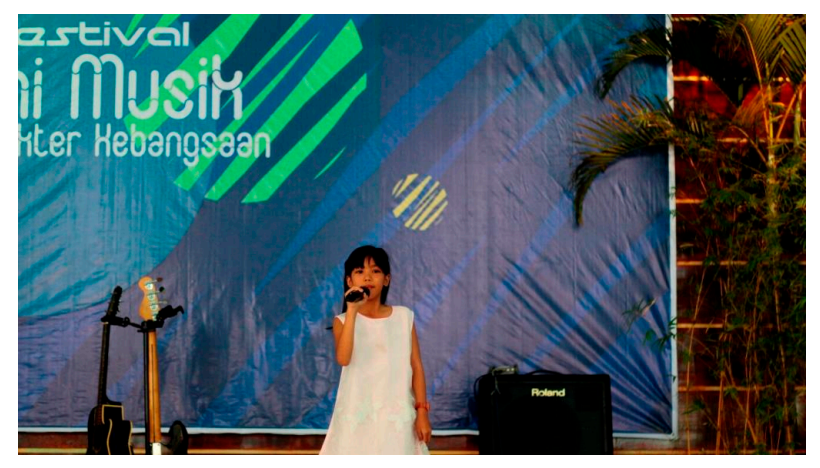

Figure 6. Music festival with the theme of national character

\section{Discussions}

Children songs have their own distinctive characters influenced by their own environment and cultural contexts. Children cannot be considered as musical embryos waiting to become musical adults, since they have their own musical culture, which consist of musical and social rules that function as a person's integration and ethnicity expression (Nettl, 2010). During the development of children song in the field, it was discovered that, seen from language aspect, the elementary school students found it easier to sing the lyric of their own national songs. Furthermore, seen from melody aspect, they had not been able to reach high notes, since the range of melody of most songs was $\mathrm{C}^{4}-\mathrm{C}^{5}$. Therefore, in addition to social and cultural aspects, the song-making process in this research also considered the appropriateness of children song.

Houlahan and Tacka (2015) propose the steps of choosing appropriate song materials that can be given in elementary school classes: (1) selecting quality musical materials; (2) choosing songs that have a musical appeal; (3) ensuring the song text and the music complements each other; and the rhythmic accent and melodic inflection match the structure of the language; (4) ensuring that the songs developmentally appropriate, which should be relevant for specific age groups; (5) selecting songs that reflect the cultural backgrounds of students in your classroom; and (6) selecting songs should be selected for their pedagogical purpose. The result of field test showed that the songs we created have formed their own quality since the students chose to perform them in the festival. The difference of songs' rhythm (4/4, 3/4, and 2/4) has made the songs becoming more dynamic and has revealed their own attractiveness. Numbers of syllables in song lyric were equated with the numbers of rhythm, in order to help elementary school students memorize the lyric and melody. In addition, the lyrics made are based on children's cultural context, which are stipulated in the national curriculum. Since the songs could be sung well, it can be interpreted that the songs made in this study are based on their age development.

The lyrics that were made based on students' cultural background have strengthened their own identity and introduced the local wisdom that must be internalized within themselves. In accordance, Elliot (2009) affirms that the provision of children security and respects can be arranged by giving status to children's own musical cultures through formal music education environment and by utilizing their spontaneous music making as a springboard for adult directed learning program. These steps are in line with the efforts to introduce folk music as their own native culture, hence, the children can know the 
tales inherited from one generation to another (R. Han \& Leung, 2015; Yang \& Welch, 2016; Yi, 2019). Moreover, it has been found that the use of technology in children song making was considered effective. The further study is suggested to develop technology-based music learning, as Wang (2019) found that there have been many online learning developed for elementary school students.

\section{Conclusions}

The findings show that the $4^{\text {th }}-6^{\text {th }}$ graders of elementary school students in West Java, Indonesia, could not reach song's melody well in the range $\mathrm{A}^{3}$ to $\mathrm{F}^{5}$ as reported in previous studies, as they were proven to be able to reach song's melodies well in the range ${ }^{\#} \mathrm{~A}^{3}$ to $\mathrm{C}^{5}$. This range is considered more representative to be used as an area in making songs for the $4^{\text {th }}-6^{\text {th }}$ graders of elementary school students in West Java. Furthermore, the development of songs using music notation software support is believed to be helpful in the process of creating and changing song composition. The implication of this study is that there is an urgency to create a simple song for elementary students in West Java, or on the opposing; the children's musical skill should be advanced for their initial age to spread a more multipart note range and interval.

\section{Acknowledgements}

An utmost gratitude is extended to the Research Institute (LPPM, Lembaga Penelitian dan Pengabdian pada Masyarakat) of Universitas Pendidikan Indonesia for facilitating this study, and the Ministry of Research, Technology and Higher Education of the Republic of Indonesia, which has funded this study.

\section{REFERENCES}

[1] .Barrett, M. S. (2010). Musical narratives: A study of a young child's identity work in and through music-making. Psychology of Music, 39(4), 403-423. doi:http://dx.doi.org/10.1177/0305735610373054

[2] Cheng, L., \& Leong, S. (2017). Educational affordances and learning design in music software development. Technology, Pedagogy and Education, 26(4), 395-407. doi:http://dx.doi.org/10.1080/1475939X.2016.1267037

[3] Elliot, D. J. (2009). Praxial music education: Reflections and dialogues: Oxford university press.

[4] Flowers, P. J., \& Dunne-Sousa, D. (1990). Pitch-pattern accuracy, tonality, and vocal range in preschool children's singing. Journal of Research in Music Education, 38(2), 102-114.

[5] Han, J., Wang, W., Zheng, C., \& Zhang, J. (2017). Host perceptions of music festival impacts: time and space matter?
Asia Pacific Journal of Tourism Research, 22(11), 1156-1168.

doi:http://dx.doi.org/10.1080/10941665.2017.1374986

[6] Han, R., \& Leung, B. W. (2015). A survey on Weifang teachers' attitudes toward teaching Chinese folk music. International Journal of Music Education, 35(2), 202-215. doi: http://dx.doi.org/10.1177/0255761415620521

[7] Houlahan, M., \& Tacka, P. (2015). Kodaly Today: A Cognitive Approach to Elementary Music Education. Oxford: Oxford University Press.

[8] Jersild, A. T., \& Bienstock, S. F. (1934). A study of the development of children's ability to sing. Journal of Educational Psychology, 25(7), 481-503.

[9] Julia, J., Hakim, A., \& Fadlilah, A. (2019). Shifting Primary School Teachers Understanding of Songs Teaching Methods : An Action Research Study in Indonesia. International Journal of Education and Practice, 7(3), 158-167. doi: http://dx.doi.org/10.18488/journal.61.2019.73.158.167

[10] Julia, J., Iswara, P. D., \& Supriyadi, T. (2018). Song creation by using computer music notation. Paper presented at the 3rd Annual Applied Science and Engineering Conference (AASEC 2018). doi: http://dx.doi.org/10.1088/1757-899X/434/1/012055.

[11] Kim, J. (2000). Children's Pitch Matching, Vocal Range, and Developmentally Appropriate Practice. Journal of Research in Childhood Education, 14(2), 152-160. doi:http://dx.doi.org/10.1080/02568540009594760

[12] Laing, J., \& Mair, J. (2015). Music Festivals and Social Inclusion - The Festival Organizers' Perspective. Leisure Sciences, 37(3), 252-268. doi: http://dx.doi.org/10.1080/01490400.2014.991009

[13] Little, N., Burger, B., \& Croucher, S. M. (2018). EDM and Ecstasy: the lived experiences of electronic dance music festival attendees. Journal of New Music Research, 47(1), 78-95. doi: http://dx.doi.org/10.1080/09298215.2017.1358286

[14] Moore, R. S. (1991). Comparison of children's and adults' vocal ranges and preferred tessituras in singing familiar songs. Bulletin of the Council for Research in Music Education, 107, 13-22.

[15] Nettl, B. (2010). Foreword. In P. S. Campbell (Ed.), Songs in their heads: Music and its meaning in children's lives: Oxford University Press.

[16] Putra, C. S. (2015). Vocal learning with the solfegio method on the gracia gitaswara choir on the gkj cilacap north of cilacap district. Jurnal Seni Musik, 4(1), 1-8.

[17] Thiagarajan, S. (1974). Instructional development for training teachers of exceptional children: A sourcebook. Indiana: Indiana University.

[18] Wang, Q. (2019). Developing a Technology-supported Learning Model for Elementary Education Level. Mimbar Sekolah Dasar, 6(1), 141-146. doi: http://dx.doi.org/10.17509/mimbar-sd.v6i1.15901

[19] Ward, S. J., Price, R. M., Davis, K., \& Crowther, G. J. (2018). Songwriting to learn: how high school science fair participants use music to communicate personally relevant 
scientific concepts. International Journal of Science Education, Part B, 8(4), 307-324. doi: http://dx.doi.org/10.1080/21548455.2018.1492758

[20] Wassum, S. (1979). Elementary school children's vocal range. Journal of Research in Music Education, 27(4), 214-226.

[21] Welch, G. F. (1979). Vocal Range and Poor Pitch Singing. Psychology of Music, 7(2), 13-31. doi: http://dx.doi.org/10.1177/030573567972002

[22] Yang, Y., \& Welch, G. (2016). Pedagogical challenges in folk music teaching in higher education: a case study of Hua'er music in China. British Journal of Music Education, 33(1), 61-79.

[23] Yi, G. J. (2019). Teaching about the Korean Ganggangsullae Folk Tradition in General Music Class. Music Educators Journal, 105(3), 45-53. doi: http://dx.doi.org/10.1177/0027432118815961 